\title{
Implementation of the 2013 Curriculum for Science Learning
}

\author{
Ana Rohmatulloh ${ }^{\bowtie 1}$, Zuhdan Kun Prasetyo² \& Haryo Aji Pambudi3 \\ 1,2 Graduate School, Universitas Negeri Yogyakarta, Yogyakarta, Indonesia \\ 3 Universitas Sanata Dharma, Indonesia \\ $\triangle$ anakuadrat@gmail.com
}

\begin{abstract}
This research aims at describing the 2013 Curriculum implementation for science learning on the planning, classroom implementation, and assessment stages, as well as the obstacles faced by teachers and their efforts to overcome them. This qualitative research was by involving Grade 4 teachers, students, and the principal of a primary school in Yogyakarta as the research subjects. The research object was the activities carried out in the curriculum implementation. The data collection instruments include observation sheets, interview guidelines, questionnaires, and analysis guidelines. The data were analyzed through data reduction, data display, and conclusion. The data validity was tested using triangulation techniques. The research found that the planning stage include studying the syllabus and teacher's books then outlining the steps of the activities with the scientific approach; the teachers had integrated the science learning with other subjects under a theme; and the scientific approach was employed through observing, questioning, experimenting, associating/reasoning, and communicating. However, the overall implementation of the 2013 Curriculum had not been optimal yet. The teachers had used authentic assessment to assess the students' attitudes, knowledge, and skills, but they rarely used assessment instruments and rubrics. The obstacles faced by teachers were in the planning, classroom implementation, and assessment stages.
\end{abstract}

Keywords: 2013 Curriculum Implementation, Primary School, Science Learning.

How to Cite: Rohmatulloh, A., Prasetyo, Z., \& Pambudi, H. (2019). Implementation of the 2013 Curriculum for Science Learning. Mimbar Sekolah Dasar, 6(1), 105-115. doi:http://dx.doi.org/10.17509/mimbarsd.v6il.15912.

INTRODUCTION The government always seeks to improve the quality of the people by adjusting the curriculum to make it always relevant to the current condition. The School-Based Curriculum developed in 2006 has been replaced with the 2013 Curriculum. Despite the intended improvement, the 2013 Curriculum still has some weaknesses in the implementation that require further review. The government, through the Regulation of the Ministry of Education and Culture No. 160 of 2014, instructed the primary and secondary schools that had implemented the 2013 Curriculum in the 2014/2015 Academic Year to re-implement the School-Based Curriculum in the second semester until further instruction. Meanwhile, the pilot schools that had implemented the 2013 Curriculum for three semesters were instructed to continue using it.

Fundamentally, the 2013 Curriculum was designed by the government to better facilitate teachers and students in the learning process. For instance, the integrative thematic method in the 2013 
Ana Rohmatulloh, Zuhdan Kun Prasetyo \& Haryo Aji Pambudi, Implementation of the 2013 Curriculum...

Curriculum does not require the students to bring many books to school. In line with this, Debara (2014: 3) states that integrative learning is essential to enable students to deal effectively with complex issues in their future working lives and the challenges in the society today and in the future.

In the 2013 Curriculum, all subjects are integrated into a theme elaborated in the 2013 Curriculum Implementation Training Module. The integration of the basic competence in science and social studies is based on its interconnected meaning with the subjects of Religion and Character, Pancasila and Citizenship, Indonesian Language, Mathematics, and Physical Education applicable in Grade 1, 2 and 3 of primary school. On the other hand, the basic competence in science and social studies of Grade 4, 5 and 6 of primary school are implemented separately and integrated into set themes.

In one of the pilot primary schools in Yogyakarta, the teachers faced various obstacles at the beginning of the 2013 Curriculum implementation. In an interview, they admitted that the time allocation for the learning process was problematic due to the abundant activities in one meeting, which made the learning process ineffective. They also faced obstacles in the selection and use of media.

To address the problems above, it is important to understand the overall implementation of the 2013 Curriculum in the school. Especially, according to the school principal, their implementation of the 2013 Curriculum has not been evaluated before and there is a limited reference for the evaluation, especially in science subjects that are often considered difficult for primary school teachers and students. This means that this research is relatively new for examining the implementation of the 2013 Curriculum for science learning in primary school level.

\section{METHODS}

This research was conducted using qualitative method. According to Creswell (2003: 9), qualitative research is largely inductive, with the inquirer generating meaning from the data collected in the field). This method could be employed if the researcher is not certain of which variables to control (Creswell, 2003). Therefore, the qualitative method would be useful in cases where the researcher wishes to gather a general (not specific) idea from the subjects with the goal being to explore, interpret, and describe a phenomenon based on the actual situation and present it in the form of words. The data were collected through observation, interviews, questionnaires, and documentation where the researchers were the key instrument. As stated by Sugiyono (2015:63), there are several data collection methods that can be used in qualitative research: observation, interview, documentation, and the combination of all (triangulation). 
The collected data include activities in planning stage, classroom implementation stage, assessment stage, as well as the obstacles and the teachers' efforts to overcome them in the implementation of the 2013 Curriculum for science learning. The subjects of this research were the Grade 4 teachers, several Grade 4 students, and the principal of a primary school in Yogyakarta. The research was conducted from January 8 until February 20, 2015.

The data validity was tested using triangulation techniques, and the qualitative data analysis was inductive. After the data were analyzed, the pattern of certain relationships or hypotheses was drawn. The data analysis in qualitative research was done before entering the field, while in the field, and after the activities in the field. However, the emphasis is the data analysis done while in the field. The components of data analysis in the field, according to Miles and Huberman (in Sugiyono 2010), presented as shown in Figure 1:

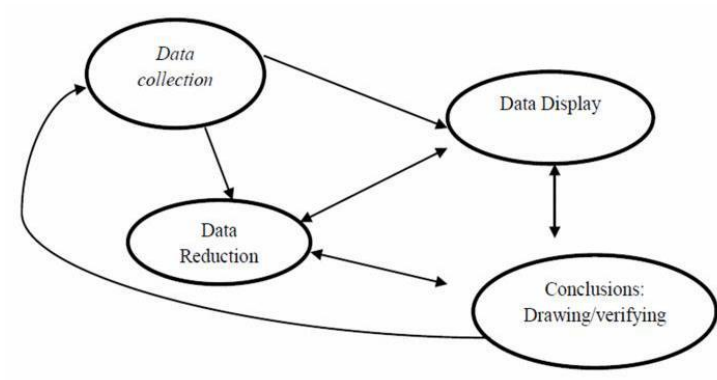

Figure 1. Data Analysis Components.

\section{RESULTS}

This research focused on the implementation of the 2013 Curriculum for science learning in the Grade 4 of a primary school in Banguntapan, Bantul, Yogyakarta, specifically in the planning stage, classroom implementation stage, assessment stage, as well as the obstacles and the teachers' efforts to overcome them. Following are the elaboration of the research findings.

\section{Planning}

The following table shows the teachers' activities in the lesson planning stage based on the observations.

Table 1. Lesson Planning Activities.

\begin{tabular}{ll}
\hline Planning & Teacher activities \\
\hline Syllabus review & $\begin{array}{l}\text { The teachers examined the syllabus to understand the Core } \\
\text { and Basic Competencies in the syllabus. }\end{array}$ \\
Teacher's book review & $\begin{array}{l}\text { The teachers examined the teacher's book to understand the } \\
\text { Core and Basic Competencies in the book. }\end{array}$ \\
The teachers developed the lesson plan based on the \\
teacher's book, including the description of the steps in \\
science learning activities.
\end{tabular}

\section{Classroom Implementation}

Based on the observations and interviews, the teachers implemented science learning using scientific approach according to the 2013 Curriculum, which consists of three main activities, namely preliminary, main, and closing activities. 
Ana Rohmatulloh, Zuhdan Kun Prasetyo \& Haryo Aji Pambudi, Implementation of the 2013 Curriculum...

\section{Assessment}

Based on the observations, the teachers conducted the assessment during the science learning process using a scientific approach as presented in Table 2.

Table 2. Implementation of Authentic Assessment for Science Learning.

\begin{tabular}{|c|c|}
\hline Indicators & Results \\
\hline Using assessment guidelines & $\begin{array}{l}\text { The teachers did not use any guideline in } \\
\text { scoring }\end{array}$ \\
\hline $\begin{array}{l}\text { Using self-assessment, peer-assessment, } \\
\text { observation, and journal }\end{array}$ & $\begin{array}{l}\text { The teachers used self-assessment to assess } \\
\text { student attitudes through observation }\end{array}$ \\
\hline $\begin{array}{l}\text { The instruments include checklists or rating scales } \\
\text { that are accompanied by rubrics, while the journal } \\
\text { is in the form of teachers' notes }\end{array}$ & $\begin{array}{l}\text { The assessment instrument used by the teachers } \\
\text { was the rating scale with the criteria of unseen } \\
=1 \text {, appearing }=2 \text {, developing }=3 \text {, developed } \\
=4\end{array}$ \\
\hline Using the mode as the criteria reference & - \\
\hline
\end{tabular}

Using the mode as the criteria reference

\begin{tabular}{|c|c|}
\hline \multicolumn{2}{|c|}{ Knowledge Competence Assessment } \\
\hline $\begin{array}{l}\text { The teachers assessed the knowledge } \\
\text { competencies through written tests, oral tests, and } \\
\text { assignments }\end{array}$ & $\begin{array}{l}\text { The teachers used written tests and assignments } \\
\text { to assess the students' knowledge }\end{array}$ \\
\hline $\begin{array}{l}\text { The written test instruments were in the form of } \\
\text { multiple-choice questions, blank-space, short } \\
\text { response, true-false, matching, and essay. The } \\
\text { essay instrument was completed with scoring } \\
\text { guidelines. }\end{array}$ & $\begin{array}{l}\text { The test instruments were in the form of } \\
\text { questions asking for a short response about the } \\
\text { environment and special characteristics of } \\
\text { animals and artworks }\end{array}$ \\
\hline Oral test instrument & - \\
\hline $\begin{array}{l}\text { The list of questions given by the teachers orally in } \\
\text { which the students responded to the question to } \\
\text { improve their courage }\end{array}$ & \\
\hline $\begin{array}{l}\text { The assignment in the form of homework and/or } \\
\text { project work was done individually or in groups } \\
\text { according to the task's characteristics } \\
\text { Using mean as the criteria reference }\end{array}$ & $\begin{array}{l}\text { The teachers gave homework about the } \\
\text { surroundings (home) }\end{array}$ \\
\hline \multicolumn{2}{|c|}{$\begin{array}{c}\text { Skills Competence Assessment } \\
\end{array}$} \\
\hline Using performance assessment & $\begin{array}{l}\text { The teachers used performance assessment to } \\
\text { assess the students' skills in the discussion report }\end{array}$ \\
\hline Using project assessment & - \\
\hline $\begin{array}{l}\text { The instruments were in the form of data, checklists, } \\
\text { and rating scales completed with rubrics }\end{array}$ & - \\
\hline $\begin{array}{l}\text { Using optimum outcomes as the criteria } \\
\text { assessment }\end{array}$ & - \\
\hline
\end{tabular}

\section{Obstacles and the Teachers' Efforts}

Based on the interviews and observations, the teachers faced several obstacles during the implementation of the 2013
Curriculum for science learning to Grade 4 students. Table 3 below shows the obstacles and the teachers' efforts to overcome them.

Table 3. Obstacles and Teachers' Efforts.

\begin{tabular}{l} 
Obstacles \\
\hline
\end{tabular}



overcome the problems related to the integration with other subjects.

\section{Assessment}

Many aspects must be assessed in the 2013 The teachers immediately recapitulate the students' Curriculum and it took a long time carry out score to avoid overload and to finish on time. Besides assessing at the end of learning sessions, the teachers also conduct a cooperative assessment with other teachers.

\section{DISCUSSION}

The learning process of the Grade 4 in the subject school using a scientific approach in the 2013 Curriculum consisted of three main activities, namely preliminary, main, and closing activities. It was based on the Regulation of the Ministry of Education and Culture No. 103 of 2014. In the preliminary activities, teachers rarely reviewed the competencies that had been learned in the previous meeting in a question-andanswer session to determine the students' level of understanding of the given material. Meanwhile, according to Sagala (2013: 226), the purpose of asking questions to students in class about the previous material is to identify the students' understanding of the material. Moreover, hardly did the teachers explain the achieved competencies in association with the benefits in their daily life. Whereas, the purpose of the scientific approach is to make the students capable to solve daily problems (Sagala, 2013: 69). Another preliminary activity that has to be done by the teachers is conveying the outline of the material and presenting the scope and assessment techniques to be used. Like the preceding activities, they hardly ever delivered the outline of the material despite it being one of the most important activities in the preliminary activities (Fadlillah: 2014: 183).

The core activities covered " $5 \mathrm{M}$ " (Mengamati, Menanya, Mengumpulkan Informasi/Eksperimen, Mengolah, Mengomunikasikan - observing, questioning, experimenting, associating/ reasoning, and communicating) according to the Regulation of the Ministry of Education and Culture No. 103 of 2014. In line with this, Akınoğlu (2008) opines that science education programs envisage an active role for students that research, monitors, experience, discuss, and solve problems like a scientist to uncover and evaluate the information needed for such activities, which constitute their own cognitive structure through activities. However, during the observation in the learning process, the students seemed to be not very enthusiastic. Here, the lack of variety in teaching activities was an obvious reason. Teachers should not have used the same teaching style during the school year, but instead provide the students the opportunity to show themselves in different activities (Mihladiz and Duran, 2014). For example, the teachers can invite the students to observe the school environment because, during the observation, the material was 
Ana Rohmatulloh, Zuhdan Kun Prasetyo \& Haryo Aji Pambudi, Implementation of the 2013 Curriculum...

about clean and healthy living. By observing the school environment, the students can gain direct experience. Simsekli (2015) highlights that primary school students' attention can be caught by practices that involve environmental problems they face or may face in their region and also practices that involve other problems. Likewise, Evrekli \& Balım (2010) suggest that mind maps to define primary school students' perceptions of environmental problems are visual tools that can provide effective learning and revealing students' initial knowledge.

Furthermore, the teachers had tried to provide opportunities for the students to ask questions during the learning process. They had shown progress in asking questions where they can start posing questions without the teachers' assistance. It is in line with Hosnan (2014: 50) who states that questioning in learning activities can raise students' skills in speaking skills, such as by making questions, giving logical and systematic answers, and use proper language structure.

Following that, the activity of experimenting had been in accordance with the Regulation of Ministry of Education and Culture No. 103 of 2014. However, the teachers eliminated the experimental activities due to the abundant work required in the preparation. This is not the most ideal because, as Fadlillah (2014: 195) explains, through some experiments, students can directly experience the phenomenon or the case problem so the material can be grasped strongly by the students as long-term memory. In line with that, McDonald (2010) asserts that the aim of science learning is to educate individuals of the most basic scientific literacy.

As for the discussion activities, the teachers guided and assisted the students in doing so with their groups. Supporting this, Rubini (2016: 300) believes that teachers are an essential component in addressing the issue of students' scientific learning. The discussion activities were done in groups. However, the group formation was only based on the seating position so the groups were always the same and homogeneous. Whereas, according to Sagala (2013: 208), discussion can foster active participation among the whole students in classes.

Furthermore, the core activity of reasoning/associating had been conducted in accordance with the Regulation of the Ministry of Education and Culture No. 103 of 2014. However, when the students were asked to draw conclusions, most of them were not participating in the activity. It was because the teachers conducted a classical question-and-answer session that was not interesting for the students. To address this, Sagala (2013) proposes to give a turn in the question-and-answer session, which is by giving a question to someone and turn to someone else. 
The reasoning activities were done on each similar sub-theme. However, during the reasoning activities on the physical characteristics of insects, it was done directly in the practice. The teachers also associated science material with Indonesian language material where the insects' physical characteristics were described in poems. The use of real examples in reasoning activities was deemed appropriate with the students' development stage, which is the concrete operational stage. Piaget, (in Santrock, 2002: 44-45) states that, at this stage, children can carry out operations and logical searches as long as the logical thinking can be applied into concrete examples.

Similar to the previous activity, the communicating activity was also done in accordance with the Regulation of the Ministry of Education and Culture No. 103 of 2014. The activities conducted by teachers were almost always constant. During the observation, the communicating activity was only found in the theme of clean and healthy living, where the teachers asked the students to write the results of their work on the board.

The students' works were to be displayed and they took turns to see, read, and comment on the work of other students. It is important because science subject in primary school needs to engage students in inquiry, in which students support claims with evidence, construct arguments, and consider alternative explanations (McNeill,
2011). Unfortunately, the teachers did not employ this activity because it was done during recess. Supposedly, giving comments on peer work is one of the activities to train students to have critical thinking. It is in accordance with one of the competencies expected from the communicating activities, i.e. developing opinions briefly and clearly as well as possessing proper language skills (Daryanto, 2014: 80).

The closing activities had been carried out in accordance with the Regulation of the Ministry of Education and Culture No. 103 of 2014. In this stage, the teachers used inductive reasoning. According to Hosnan (2014: 73), inductive reasoning is done by drawing conclusions from phenomena or special attributes for general things. Unfortunately, the teachers rarely made summary or lesson conclusions in the closing stage.

The teachers carried out the reflection activity by asking the students what they have learned. Unfortunately, the teachers rarely reflected on the activities that had been carried out. Whereas, they can actually do alternative reflection activities, such as asking students about their impressions or even their suggestions for the learning. Rusman (2011: 10) states that reflection is a way of thinking about what just happened or been studied. In line with this, Sani (2014: 270) reveals that one type of feedback that can be done is enrichment. Then, Rusman (2011: 10) suggests conducting follow-up activities in 
Ana Rohmatulloh, Zuhdan Kun Prasetyo \& Haryo Aji Pambudi, Implementation of the 2013 Curriculum...

individual or group assignments. These follow-up activities were also missed by the teachers. The last activity carried out by the teachers in the closing activity was explaining the lesson plan for the next meeting. According to Sagala (2013: 229), information about the materials to be discussed in the next meeting is needed so students can learn about the material, but it should be accompanied by the learning plans for the next meeting and the teachers did not do it.

Based on the results of the research, the teachers assessed three competencies in the learning process, namely attitude, knowledge, and skills. To assess the students' attitudes, the teachers only used observation. However, there are other techniques in the form of self-assessment, such as peer and journal assessment, as stated in the attachment of the Regulation of the Ministry of Education and Culture No. 104 of 2014. In the case of the students' knowledge, the teachers employed written test instruments from which several activities can be done to assess the students' knowledge like written tests, discussions observations, questionand-answer sessions, and assignments. This means that the teachers need more variation in their assessment system, which can be orally or through written assessments. In fact, the students' homework was often just discussed together without being scored.

On another note, the teachers utilized performance and project assessments to assess the students' skills in science learning. The teachers also referred to the optimum achievement criteria for skills assessment. Daryanto (2014: 126-127) points out that attitude assessment is done through performance, project, and portfolio scoring. According to the Regulation of the Ministry of Education and Culture No. 104 of 2014, the instruments include checklists or rating scales accompanied by rubrics, and the final results are calculated based on the optimum performance. However, in the implementation, the teachers did not use the assessment instruments. The scores were only in the form of numbers with a range of 1-100. It indicated that the teachers were not fully aware of the importance of the assessment instruments and rubrics.

In addition, the teachers did not use portfolio assessment in assessing the students' skills although portfolio assessment can show the progress of the students' works. Hamrin \& Toth (2012: 509) clarify that portfolio assessment can develop self-management skills and can be widely adapted to various education levels. The teachers gave some written test, such as daily tests, final test of subthemes/ themes, mid-test, and final test. The teachers always distributed the test results to the students and the principal at the end of each semester. This is in line with the assessment principles of the 2013 Curriculum, where learning procedures, assessment criteria, and results should be 
transparent and accessible for all parties (Fadlillah, 2014: 203).

There were some obstacles faced by the teachers in the planning, classroom implementation, and assessment stages. In the planning, the teachers found it difficult to develop the learning activities using the scientific approach and assessment instruments as well as integrating science with other materials due to the lack of the teachers' knowledge. According to Sani (2014: 264), learning activities should be adjusted to the of students' development in order to have appropriate methods and techniques in improving their ability, interest, and level of learning readiness. The effort made by the teachers to overcome these obstacles was by having a discussion with other teachers on alternative learning activities using the scientific approach. In line with this, Hosnan (2014: 107) suggests that discussing problems with peers or the principal can serve as an immediate solution for teachers.

The teachers also faced some problems in the implementation of science learning because they could not come up with variations in learning activities using a scientific approach. It caused the students to be less enthusiastic to participate in the learning process. Here, the teachers need to provide interesting activities so the students are excited to participate in the learning process (Hosnan, 2014: 106). Hamrin \& Toth (2012: 37) also highlight that one of the teacher's tasks is to inspire students to be actively and productively involved in learning. The effort made by the teacher to overcome these obstacles was to discuss alternative learning activities using the scientific approach with other teachers.

Another obstacle was faced in the assessment stage of science learning. Since there were many aspects that must be assessed in the 2013 Curriculum, the teachers needed a long time to complete the assessment. To overcome these problems, they recapitulated the students' scores directly to avoid overloaded assessment. They made the assessment immediately after the learning process ended. They also anticipated these obstacles by cooperating with other teachers in the assessment process.

\section{CONCLUSION}

The results of the research showed that the planning stage for science learning carried out by the teachers to follow the 2013 Curriculum includes reviewing the syllabus and teacher's books and developing the lesson plan with a scientific approach. The teachers had implemented science learning by integrating different subjects using different themes and the " $5 \mathrm{M}$ " activities (observing, questioning, experimenting, associating/reasoning, and communicating). However, the overall implementation of the 2013 Curriculum in science learning had not been optimal yet. The teachers had used authentic assessment to examine the students' 
Ana Rohmatulloh, Zuhdan Kun Prasetyo \& Haryo Aji Pambudi, Implementation of the 2013 Curriculum...

attitudes, knowledge, and skills, but they rarely used assessment instruments and rubrics. The obstacles faced by the teachers in the implementation of the 2013 Curriculum for science learning were in the planning, classroom implementation, and assessment stages.

\section{REFERENCES}

Akınoğlu, O. (2008). Assessment of the Inquiry-Based Project Implementation Process In Science Education Upon Students' Points of Views. International Journal of Instruction, 1(1), 1-12.

Creswell, J. W. (2003). Research design: Qualitative, quantitative, and mixed method approaches. London: Sage Publications, Inc.

Daryanto. (2014). Pendekatan Pembelajaran Saintifik Kurikulum 2013. Yogyakarta: Gava Media.

Debara. (2014). Why Integrative Learning? Why Now? Retrieved from ProQuest documentreport,Information, from, Pro Quest.s://www.google.com/search?q $=$ ProQuest+document+link\&oqProQue st+document+link\&aqs=chrome..69i57 .4655 j0j8\&sourceid $=$ chrome \&ie $=$ UTF$826 \quad$ September 2014 19:19.file:///E:/journal\%202/journal\%20 14.pdf.

Evrekli, E,. \& Balım, A. G. (2010). Effects of mind map and concept strips use in science and technology education on students' academic achievement and perception of inquiry learning skills. Batı Anadolu Eğitim Bilimleri Journal, 1(2), 76-98.

Fadillah, M. (2014). Implementasi Kurikulum 2013 Dalam Pembelajaran SD/MI. SD/MTS, dan SMA/MA. Yogyakarta: ArRuzz. Faridah Alawiyah.

Hamrin, Merril \& Melanie Toth. (2012). Pembelajaran Aktif yang Menginspirasi: Buku Pegangan Lengkap untuk Masa Kini. (Alih Bahasa: Bethari Anissa Ismayasari). Jakarta: PT. Indeks.
Hosnan, M. (2014). Pendekatan Saintifik dan Kontekstual dalam Pembelajaran Abad 21 Kunci Sukses Implementasi Kurikulum 2013. Jakarta: Ghalia Indonesia.

Kemdikbud. (2013). Permendikbud, Nomor 160, Tahun 2013, tentang Kurikulum 2006 dan Kurikulum 2013.

Kemdikbud. (2013). Peraturan Pemerintah RI Nomor 67, Tahun 2013, tentang Kurikulum SD.

Kemdikbud. (2013). Permendikbud, Nomor 66. Tahun 2013, tentang Standar Penilaian Pendidikan.

Kemdikbud. (2014). Permendikbud, Nomor 103, Tahun 2013, tentang Pembelajaran pada Pendidikan Dasar dan Pendidikan Menengah.

McNeill, K. (2011). Elementary students' views of explanation, argumentation, and evidence and their abilities to construct arguments over the school year. Journal of Research in Science Teaching, 48(7), 793-823.

McDonald, C. V. (2010) The influence of explicit nature of science and argumentation instruction on preservice primary teachers' views of nature of science. Journal of Research in Science Teaching, DOI 10.1002/tea.20377.

Mihladiz and Duran. (2014). Views of Elementary Education Students Related To Science and Technology Teaching Process. Procedia - Social and Behavioral Sciences 141 (2014) $290-297$.

Rubini (2016). Identify Scientific Literacy From The Science Teachers' Perspective. Science Education Program, Postgraduate Program Pakuan University, Bogor, Indonesia.

Rusman. (2011). Model-model Pembelajaran: Mengembangkan Profesionalisme Guru. Jakarta: PT. Raja Grafindo Persada.

Simsekli. (2015). An Implementation to Raise Environmental Awareness Of 
Elementary Education Students. Procedia - Social and Behavioral Sciences 191 ( 2015 ) $222-226$.

Sugiyono. (2015). Metode Penelitian Kombinasi (Mix Methods). Bandung: Alfabeta.

Sagala, Syaiful. (2013). Konsep dan Makna Pembelajaran. Bandung: Alfabeta.

Sani, Abdullah Ridwan. (2014). Pembelajaran Saintifik untuk Implementasi Kurikulum 2013. Jakarta: PT. Bumi Aksara.

Santrock, John W. (2002). Life-Span Development: Perkembangan Masa Hidup, Edisi 5, Jilid II. (Alih Bahasa: Juda Damanik dan Achmad Chusairi). Jakarta: Erlangga.

Sugiyono. (2010). Metode Penelitian Pendidikan: Pendekatan Kuantitatif, Kualitatif dan $R$ \& $D$. Bandung: ALFABETA. 